\title{
Diplomats, Quo Vadis? The determinants of Brazilian diplomatic presence
}

DOI: http://dx.doi.org/10.1590/0034-7329201900114

Rev. Bras. Polít. Int., 62(1): e014, 2019

Revista Brasileira de Política Internacional ISSN 1983-3121

http://www.scielo.br/rbpi

\section{Rafael Mesquita ${ }^{1}$}

${ }^{1}$ Federal University of Pernambuco, Political Science Department, Recife, Brazil. (rafaelmesquita_5688@hotmail.com)

iD ORCID ID: orcid.org/0000-0001-6042-1606

\section{Marcelo de Almeida Medeiros ${ }^{2}$}

${ }^{2}$ Federal University of Pernambuco,

Political Science Department, Recife, Brazil. (mam14@pq.cnpq.br)

iD ORCID ID:

orcid.org/0000-0001-8385-0358

\section{Luiza Vilela Amelotti ${ }^{3}$}

${ }^{3}$ Federal University of Pernambuco, Political Science Department, Recife, Brazil. (luvamelotti@gmail.com)

\section{Copyright:}

- This is an open-access article distributed under the terms of a Creative Commons Attribution License, which permits unrestricted use, distribution, and reproduction in any medium, provided that the original author and source are credited.

- Este é um artigo publicado em acesso aberto e distribuído sob os termos da Licença de Atribuição Creative Commons, que permite uso irrestrito, distribuição e reprodução em qualquer meio, desde que o autor e a fonte originais sejam creditados. 
same warning was repeated in the early days of the Jair Bolsonaro government, who actually did close Brazilian embassies, albeit in the Caribbean. ${ }^{3}$

The African saga highlights a hitherto underexplored domain of foreign policy: the choice of how a country places its foreign representations and the dynamics behind this process. A country's diplomatic network is both a sign of its resources and of its relational preferences. Furthermore, the placement of such capabilities is an outcome of the foreign policy making process and can hence be the product of conflicting interest and agendas. Why do some states receive more diplomatic attention than others? What types of key concerns drive the distribution of foreign policy resources? This study will address those questions by specifically analyzing the allocation of Brazil's diplomatic personnel abroad.

Brazil is a noteworthy case for this investigation, due to its structural insertion, regional policy, and diplomatic tradition. As with other developing states, it has been structurally bound to attach greater emphasis to advanced economies. Yet, Brazil's moderate economic and political weight does grant it some latitude in choosing its priorities. Historically, the country has swung from prioritizing the developed world towards inclinations in the direction of Third-Worldism. Likewise, the centrality of its own geographical region has been ambiguous. With the ongoing shift from a US unipolar order to a more multipolar scenario, it is unclear how an intermediate power such as Brazil will choose to update its diplomatic network.

Furthermore, such movements take place against an institutional background. Brazil's Ministry of Foreign Affairs (Ministério das Relaçôes Exteriores - MRE), also known as Itamaraty, has traditionally been regarded as a highly professional bureaucracy, enjoying sizeable autonomy in conducting Brazilian foreign policy. Yet, this insulation has not remained unchanged as the nation and the very practice of external affairs evolved. This begs the question of whether the global expansion of Brazil's foreign policy produced symmetric effects on its diplomatic bureaucracy. That is, if the MRE adapted itself to the dawning multipolarity, or if there was institutional inertia keeping the corps attached to traditional centers.

The goal of this article is to understand this question through analysis of longitudinal data on Brazil's representations overseas. We test several determinants to assess their weight in influencing mission size from 2008 to 2015. This article's contribution is thus fourfold. We seek firstly to enrich the literature on the determinants of diplomatic presence through the case study of a middle-range power from the Global South. ${ }^{4}$ Secondly, we offer evidence on how the evolving multipolarity of our time is reshaping diplomatic priorities. Thirdly, we will address some of the questions that have been lingering in the Brazilian foreign policy research field relating to the country's external preferences. Though many discussions have revolved around whether Brazil values Northern or Southern connections, there has been no standard approach to

\footnotetext{
3 "Itamaraty fecha cinco embaixadas brasileiras no Caribe", Veja (Braun 2019).

${ }^{4}$ To the extent of our knowledge, empirical assessments so far have focused on Europe. Webster and Ivanov (2007) analyze the effect of EU membership in Bulgaria and Romania’s diplomatic presence, while Webster and Hadjimanoli (2014) perform the same study for Cyprus.
} 
assess which partners matter most for Brasilia. ${ }^{5}$ Our focus on mission size - a costly asset - will offer a valid metric to answer this query. Lastly, this research also adds to the scholarship on institutions and bureaucracies by focusing on the MRE, which is a clear case of an organization facing change. Little is known on the factors that influence the size, prestige, and importance of Brazil's missions worldwide. If global polarity is changing and, allegedly, Brazil's external priorities too, how is the MRE adapting to such shifts? Does the Ministry accompany such developments in its policies on post ranking and status? Do Brazilian diplomats, in turn, want to be there where policy requires them to?

The investigation is carried out in five stages: (1) a review of the theoretical arguments regarding the determinants of diplomatic representations; (2) an appraisal of the external and internal processes that have impacted Brazil's foreign policy in recent years; (3) a presentation of our research design, hypotheses, and data; (4) results and discussion; and (5) the conclusion.

\section{Determinants of diplomatic presence}

What determines the existence and size of a diplomatic mission in a host state? The pursuit of self-interest by the sending nation, be it short or long-term. This falls within a broadly realist ontological perspective, which nowadays would encompass social, economic, and political aspects, conditioned also by the technological revolution, globalization, and its effects on the exercise of power. Naturally, the strategies and perceptions of states are nuanced: while some favor immediate factors, others lean on longer-term aims. Or, as underscored by Brams (1966), Singer and Small (1966, 241), Small and Singer (1973, 581), and Wallace $(1971,26)$, on a combination of these attributes. That is, a diplomatic mission is established when the receiving state is a relevant actor in multiple dimensions. However, which dimensions are these?

The existence and the magnitude of a diplomatic mission are the highest degree of mutual acknowledgement between actors (Wouters et al. 2013, 511). The costs involved in opening and maintaining a representation are a practical limitation which often compels parties to set priority criteria. This is a classic trade-off, as opening an embassy in one place possibly means not opening it elsewhere. Thus, it is necessary to investigate, amidst the plethora of relevant dimensions, which ones are most important.

Based on an exhaustive literature review, Duque $(2018,579)$ presents a typology grouping relevant dimensions in two main categories: material resources and fundamental values. Among the former, she underscores economic, military and technological capabilities - features regarded as salient by a several authors. As for the latter, scholarship highlights: political system or ideology, culture or civilization and, finally, moral superiority. ${ }^{6}$ Another important variable in explaining

\footnotetext{
${ }^{5}$ See, however, Rodrigues et al. (2019) for a recent attempt.

${ }^{6}$ However, some of the surveyed authors contribute to both categories: Gilpin, Larson \& Shervchenko, Neumann, Luard and also Schweller. For more details, see Table 1 at Duque $(2018,579)$.
} 
variation in diplomatic representation, as suggested by Karns and Mingst $(2013,142)$ and by Hampson et al. $(2013$, 320), is whether the state headquarters Inter-Governmental Organizations (IGOs). ${ }^{7}$ While it is acknowledged that the listed attributes matter, their relative contribution to the size of a diplomatic mission is still unknown.

Additional reasons could equally impact on the size of a diplomatic mission. Analyzing the US-UK tandem, Smith $(1990,135)$ shows that the international scenario is characterized by what he calls special relationships. He argues, however, that such bonds occur between governments and not national societies, as the latter can, under certain circumstances, entertain different worldviews. In the same vein, a second clue is offered by Hocking and Lee (2006), which propose the notion of Enhanced Representation, which, as they understand, transcends the specific US-Canada case, since this idea comprises general problems, common to any government attempting to reconcile proximity pressures with the growing number of relations which undertake, in some form, a character of specialness. The analyses by Smith (1990), and Hocking and Lee (2006), suggest that, in fine, there are special relationships in world politics and that those state bureaucracies which are well aligned and determined should ensure that these links become enduring. Often, this is translated via a greater number of bilateral agreements, which act as catalysts and guiding posts. As stressed by Art $(1973,486)$ once the internal and external constraints are known, the bureaucracy can perform a relevant role.

The dynamics of bureaucracies in face of external stimuli have been approached frequently in political science. Mary Douglas, based on Durkhein and Fleck $(1986,126)$, argues that "institutions systematically guide individual memory and channel our perceptions in ways compatible with the relationships that authorize them. They render essentially dynamic processes fixed, hiding their influence and triggering our emotions in a standardized extreme on standardized questions." Taking into account Bennet and Howlett's (1992) discussion on policy learning and policy change, the concern is to investigate how Itamaraty's bureaucracy has addressed the dynamism of diplomatic reality and the need to galvanize guiding perceptions.

It is important to stress that we approach bureaucracies by emphasizing the employees and the relationships among them, as suggested by Crozier (1971). That is, we assume an insulation between hierarchical levels, leading to a chasm between goals. High and low-level bureaucrats are at odds: the former closely adheres to the guidance originated at the seat of political power; the latter, less permeable, seek instead "a quiet life which may best be ensured by slavish adherence to the rules, whatever they are" (McLean and McMillan 2009, 55). As highlighted by Girglioli (1997, 129), this is a perspective focusing on the conflicts within the legal-bureaucratic logic. Hence, our premise is that the average Itamaraty employee rationally calculates his/her actions, with regards to his/her navigation through the bureaucratic network, seeking chiefly self-benefit.

\footnotetext{
7 "The rapid growth in the number of international institutions in the $20^{\text {th }}$ century [...] gave further impetus to international negotiation processes [...]. The obvious importance states attach to these bargaining processes is reflected in the sizeable cadre of professional international negotiators who are to be found not just in foreign ministries, but also in the many different functional departments and agencies of national governments that deal with cross-border issues" (Hampson et al. 2013, 320).
} 
Thus, this article articulates some of the dimensions summarized by Duque, placing them in a special matrix of internal and external constraints evoked by Art (1973), complemented with the notions of special relationships and of the bureaucratic paradigm as applied to Itamaraty. In short, as we will expound, the determinants of diplomatic presence refer to (1) external/structural, (2) bilateral (special relationship) and (3) bureaucratic factors.

\section{Brazilian foreign policy in a changing international landscape}

The US-led unipolar moment after the Cold War was rather brief. The main change took place with the rise of large economies from the global semi-periphery in the 2000s. They have both tilted the world economic epicenter and started to claim a more assertive role in global affairs, as crystallized with the emergence of the BRICS countries (Brazil, Russia, India, China and South Africa).

Though the literature is not unanimous regarding the rise of such countries as the harbinger of true multipolarity ${ }^{8}$, it is clear that the new actors are currently changing the distribution of power in the global arena. How does this restructuring affect the priorities and preferences of an intermediary country like Brazil? In order to answer that question, it is necessary to review the literature on the evolution of Brazil's bilateral affinities.

\section{The Brazilian crux: between North and South, the region and the world}

Fonseca Jr. (1998) argues that during the Cold War, Brazil remained a thoroughly Western nation, though deliberately keeping the meaning of this label elastic. Culturally and historically, as put forth by Steiner et al. $(2014,43)$, Brazil is "the most Western of the emerging economies." Since re-democratization, its paths to international insertion have also oscillated between integration and independence. In the 1990s, its main concern was recovering credibility before advanced democracies, but in the next decade it would welcome diversified South-South cooperation, a more autonomist agenda, and bolder claims to regional leadership (Vigevani and Cepaluni 2011).

This leads to the question of how important the region is. Though successive administrations have unvaryingly underscored the primacy of South America, scholarship remains divided. Some authors emphasize that Brazil sees the region merely as a stepping-stone for global ambitions (Spektor 2010; Vigevani and Cepaluni 2011; Lazarou and Theodoro 2015), or that Brasilia stands astride its region and the world (Malamud and Rodriguez 2014), and that its Global South identity at times eclipses its South American one (Mesquita and Medeiros 2016).

The choice between alignment with the wealthy West versus the Global South and its counter-hegemonic tendencies is an ongoing process (Rodrigues et al. 2019), not least because such dichotomy reflects fault-lines within Brazil's own political elites, even within Itamaraty

\footnotetext{
${ }^{8}$ Cf. Cooper (2013) and Jacobs and Rossem (2014).
} 
itself (Mesquita 2016; Saraiva 2010). Thus, external forces interact with domestic factors in determining Brazil's diplomatic presence abroad, which makes it necessary to pay closer attention to its internal institutions.

\section{Itamaraty: institutional trajectory}

In this section, we explore the domestic actor that has historically played the most important role in formulating and implementing Brazil's foreign policy: the MRE. Based on a Weberian typology, Cheibub (1985) argues that the Ministry has evolved significantly in the course of its centennial history, from being a gentlemanly cabinet into a fully formal state bureaucracy.

Regarding the early efforts to train Brazilian diplomats, the author states that the Rio Branco Institute (Instituto Rio Branco - IRBr) was created to provide an ideational standard concerning international politics. Military institutions were a prompt inspiration. The training continuity found in both bureaucracies (diplomatic and military) regarding formation, rules of merit, and seniority, and career promotions testify to this similarity. According to Almeida et al. $(2012,8)$, because MRE had "strong esprit de corps, institutional memory, specialized training, and specific competencies," its monopoly on Brazil's foreign affairs helped to characterize this policy as a state policy; constant and predictable.

Analyses of the post-authoritarian period, in turn, tend to underscore Itamaraty's prolonged insulation. Figueira (2010) argues that the organ's openness to outside actors is issue-specific. Lopes $(2014,498)$, in turn, believes that the MRE remains a largely aristocratic entity, in spite of the growing participatory revindications. The single actor who has gained most agency in recent years regarding foreign policy is undoubtedly the Presidency, as the foremost representative of the country abroad (Cason and Power 2009)

Lastly, the Ministry's robustness has also varied according to governmental priorities and budgetary availability. During the late 2000s, when Brazil experienced great economic growth, the MRE's operations also expanded, both in terms of diplomatic presence and human resources. ${ }^{9}$ This grand moment, however, came to a quick end. Brazil's economic stagnation in the 2010s, the personal lack of interest in foreign policy of the new president, Dilma Rousseff, and the decrease in the MRE's political clout relative to other ministries have pushed Itamaraty into a dark phase (Stuenkel 2014). ${ }^{10}$

\section{Itamaraty's policies on post ranking and personnel placement}

In this section, we assess MRE's administrative configuration and personnel policy, as detailed in its legislation and internal norms. At the moment this article was written, the main piece of

\footnotetext{
${ }^{9}$ At the height of that decade's prosperity, the IRBr jumped from graduating 20-30 diplomats to 100 at a time (Bancillon 2016).

${ }^{10}$ The Ministry's first-ever employee strike in August 2016 over salary readjustment further demonstrated the extent to which it had become marginalized.
} 
legislation affecting the organizational structure of the Ministry was the Decreto n. 5.979 from 06 December 2006 (Brasil 2006), and its later revisions. ${ }^{11}$ The competences and duties of the members of the Ministry are also spelled out in this decree and in MRE's 2008 internal regiment (Ministério das Relaçóes Exteriores 2008). The decision chain concerning the definition of staff size for missions abroad and their ranking begins with propositions by the Director of the Department of Foreign Service. These recommendations make their way up to the Minister of State, who ultimately decides on the issue. The process can be synthesized as in Figure 1:

\section{Figure 1. Process for proposing ranking and staff size of Brazil's posts overseas}

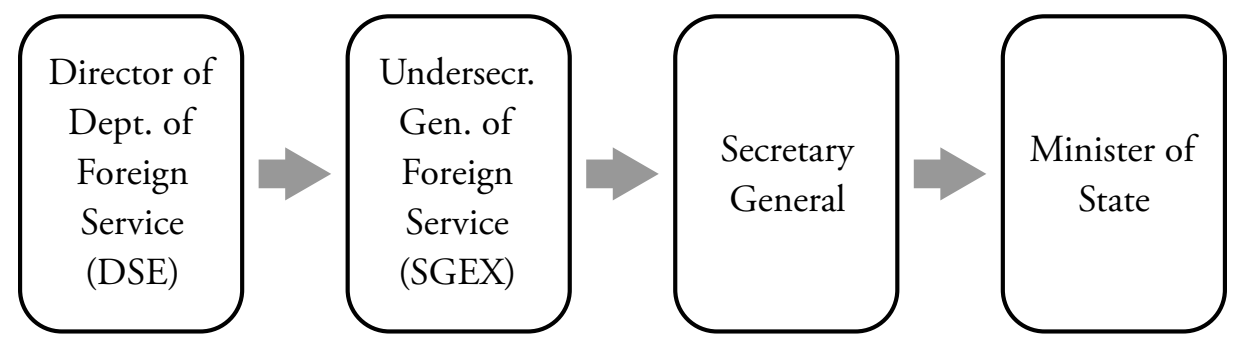

Source: elaborated by the authors, based on $M R E$ s internal regiment (Ministério das Relaçóes Exteriores 2008), specifically articles 31, 161 and 217, and personal communication with MRE staff (May 2017).

From 1997 and onwards, the overseas personnel lists published by the MRE show the ranking of each post abroad. ${ }^{12}$ Ranks varied from A to C from 1997 until 2006 and A to D from 2007 onwards. According to Art. 13 from Law n. 11.440 (29/12/2006) (Brasil 2006b), the end goal of the ranking system is "personnel movement" (movimentação de pessoal) ${ }^{13}$ and it is carried out by the MRE following three criteria: "the mission's degree of significance, the specific living conditions at the headquarters, and the administration's convenience." ${ }^{14}$ Thus, countries which enjoy high quality of life and also are strategic for Brazil's foreign policy should have predominantly $A$ and $B$ posts, while those states with low living conditions and no strategic significance rank lower, all mediated by the administration's discretion. The ranking works as an incentives system: employees stationed at lower posts can receive higher salaries and benefits, and be first in line when vacancies open up in top-ranking stations, among others. The goal of this scheme is to try to reconcile MRE's need to occupy "hard places" and the staff's preference for more agreeable

\footnotetext{
${ }^{11}$ This document was edited by later documents, the most recent being the Decreto no 9.683 in 2019 (Brasil 2019). The seven organs of the Ministry's structure remain the same. There were minor changes in the distribution of functions and names of the departments and/or secretaries to which they are attached. For instance, a "Department for the US" was created, while Canada was attached to the "Department for Mexico, Central America and the Caribbean," Overall, the core of the 2008 Regiment remained intact.

${ }_{12}$ Mentioning to the A-C ranking system appears as early as the Decreto no 93.325, from 01/10/1986 (Brasil 1986). However, personnel lists prior to 1997 do not show any information on post ranking.

${ }^{13}$ All three careers of the Foreign Service (Diplomat, Chancellery Officer and Assistant) are concerned.

${ }^{14}$ All translations in this article were provided by the authors.
} 
destinations. ${ }^{15}$ Under the current system for personnel placement, the State Minister announces to the employees which posts are vacant, and candidates can apply for some destinations in order of personal preference. Yet, after the selection is concluded, no staff member is obligated to take a position in a given post. Therefore, the MRE has no tool, other than some career benefits, to convince employees to move to harsher countries.

Though the MRE frequently attracts academic interest, its personnel-related affairs have received minor attention. ${ }^{16}$ An important breakthrough in this domain was accomplished by Farias and Carmo (2015), who built an impressive dataset covering the creation of posts from 1819 to 2010 and tracking the careers of 1768 diplomats. The authors offer a thorough overview not only of the quantitative distribution of diplomatic assets, but also of the evolution of the Ministry's administrative and legislative frameworks.

Their main finding resonates with our central focus. Though the network of Brazilian embassies and consulates expanded so as to keep the pace of diversifying international interests, diplomats have clung to traditional posts in Europe and North America. The goals of the administration (to populate all stations according to national objectives) are frequently at odds with those of diplomats (who prefer places with better quality of life and career prospects) ${ }^{17}$, and incentives for preference change are small. Farias and Carmo's data indicate that diplomats who serve in prestigious countries reach the top of their careers faster and more frequently than those serving elsewhere. ${ }^{18}$ The Ministry's shortcomings in effectively implementing more predictable, transparent, and impersonal personnel allocation protocols have also curtailed the credibility of reform attempts.

Our work seeks to go beyond Faria and Carmo's contribution by providing not only descriptive but also correlational inferences in two aspects: assessing which variables influence the MRE's attribution of post ranking and which affect personnel movement. We attempt to provide such explanations resorting to multivariate regression, as we explain in the next section.

\section{Data, variables and hypotheses}

This research is designed to uncover the determinants of Brazil's diplomatic presence. Specifically, we focus on mission size per country, as measured by the amount of total diplomatic staff on the

\footnotetext{
${ }^{15}$ For some of Itamaraty's staff, both the ranking system and the planning for determining the size of the staff at each mission are not sufficiently clear. According to the 2017 president of the labor union of Itamaraty employees (Sinditamaraty), Suellen Paz, the classification criteria are not clear, so that the ranking serves mainly as an instrument for handling personnel placement. Regarding staff size, she states that there are no established criteria for how large a station should be, apparently due to a lack of strategic planning on the part of MRE (Personal communication, May 2017).

${ }^{16}$ See, however, Teixeira and Steiner's (2017) study on women in the Brazilian diplomatic service.

${ }^{17}$ Some reasons for personnel deficit in harsh locations are unattractive salaries, lack of security, poor infrastructure, and everyday living difficulties for employees with families with children in school age (Personal communication with the president of Sinditamaraty and other MRE staff, May 2017)

${ }^{18}$ The service track of the Foreign Relations Ministers and Secretary Generals testifies to the success of this strategy: the diplomats who held those positions spent $76 \%$ of their careers in Europe and North America and only $2 \%$ in Africa, Asia, the Middle East and Oceania.
} 
ground, since this can be an indicator of a partner's relevance. As the MRE simultaneously decides not only on post size, but also on its ranking, and given that this classification is expected to affect personnel movement, we test for the determinants of this ordering as well. By speaking of determinants, it is implied that we wish to confront competing causal factors and assess what is, ceteris paribus, their relative contribution. Due to data availability, we will concentrate on the time period between 2008-2015, as data for some of our variables were either unavailable (e.g.: population estimates) or underwent measurement changes (post ranking) in previous years. Below we explain in detail our data, hypotheses, and method of choice. For more extensive details, we refer to this article's annexes. ${ }^{19}$

\section{Dependent variables}

The dependent variables in this study are (1) post ranking and (2) post size - as measured by the total number of stationed personnel. This information was obtained from the Rising Powers Diplomatic Network (RPDN) dataset (Mesquita 2019). The total count of employees combines all listed staff (diplomats, chancery officers, and assistants).

\section{Independent variables}

As mentioned, the determinants of diplomatic presence are classified in different groups: structural/external, bilateral (special relations status), and bureaucratic.

\section{External and structural factors}

Following the template adopted by Webster (2001), Neumayer (2008) and Kinne (2014), structural factors will be operationalized through measures of national wealth, trade, hosting of IGOs, geographical distance, and contiguity. We use GDP as an indicator for a country's power and wealth; total bilateral trade with Brazil; number of IGOs headquartered in the country; a dummy for geographical contiguity; and distance between capitals.

\section{Special relations status}

Based on Smith (1990), Hocking and Lee (2006), Webster and Ivanov (2007), and Webster and Hadjimanoli (2014) we have operationalized the concept of special relations through the volume of bilateral agreements; size of expatriate community, and membership of specific interstate groups. It is particularly challenging to operationalize the concept of strategic partnerships or special relations, due in part to its overuse by officialdom (Lessa and Oliveira 2013). In order to establish whether any country had special relations with Brazil, we counted the number of bilateral agreements signed between them, as recorded at MRE's online repository, Concordia.

${ }^{19}$ The Annex, original datasets and replication materials can be found in Dataverse (Mesquita et al. 2019) 
Migration-related factors might also be of significance. It is expected that MRE missions increase in complexity according to the demands of the resident Brazilian population. A larger expatriate community implies a greater load of consular work (e.g.: civil certificates, passports, etc.), thus requiring more staff. In order to count the number of Brazilians living abroad, we consulted a series of population estimates published by the MRE between 2008 and 2015 .

Lastly, membership within certain key political and economic blocs has also been modeled. Specifically, the G7, BRICS, Mercosul, and the Community of Portuguese-Speaking Countries (CPLP) groups were considered. The first two must be compared in order to contrast the relevance of traditional powers against emerging poles. The latter two are also necessary to account for the priority of the region, and of Lusophone countries, which have received growing attention, according to recent scholarship (Lima 2014).

\section{Bureaucratic factors}

Based on Douglas (1986) and Bennett and Howlett (1992), bureaucratic factors refer to: Post Tradition, Post Ranking, and Inertia. Post tradition was measured through the opening year of embassies abroad. It was considered that older posts are more traditional and, therefore, more coveted by MRE employees. We have gathered information on embassies and consulates, while legations and honorary stations were discarded. In total, we covered approximately 640 city-level records. Based on the decade when an embassy was first opened (or upgraded, if a previous station was not an embassy), countries were ranked on a 12-point scale.

Information on our second bureaucratic indicator, post ranking, was available at the RPDN dataset. Its four hierarchical values (A to D) were converted to a numerical scale ( 3 to 0 ). Values are assigned to individual posts within cities, so that country-level values refer to an overall national mean.

Thirdly, language can also be an important barrier or gateway for service abroad. In order to function properly in a foreign country, an employee is expected to have working knowledge of its official languages. As it is not possible to assess the linguistic skills of every employee, we chose the Ministry's language training as a proxy. Three languages are mandatory in IRBr's curriculum: English, Spanish, and French, also being required in admission exams. Hence, MRE employees are expected to be more inclined to work in countries wherein the official language is either Portuguese or one of the three mandatory IRBr languages.

Lastly, diplomatic inertia was calculated as the number of diplomatic personnel at each post in the preceding year. In other words, through lagged dependent variables.

\section{Summary and hypotheses}

Table 1 provides a summary of our data. The columns present the four groups of determinants, all concepts, their respective empirical indicators and data source. The last column summarizes our working hypothesis for each variable, that is, whether its effect on amount of personnel should be positive or negative. 
Table 1. Summary of variables, sources and hypotheses

\begin{tabular}{|c|c|c|c|c|}
\hline $\begin{array}{l}\text { Group of } \\
\text { determinants }\end{array}$ & Determinant & Empirical indicator & Data source & Effect on DV \\
\hline \multirow{5}{*}{$\begin{array}{l}\text { External and } \\
\text { structural }\end{array}$} & Contiguity & Shared land border & CEPII & + \\
\hline & Distance & $\begin{array}{l}\text { Weighted distance between } \\
\text { capitals }\end{array}$ & CEPII & - \\
\hline & Wealth & GDP (bi constant 2010 USD, log) & World Bank & + \\
\hline & Trade & $\begin{array}{c}\text { Total trade (bi constant } 2010 \\
\text { USD, log) }\end{array}$ & UN Comtrade & + \\
\hline & IGO headquarter & $\begin{array}{l}\text { Number of IGOs headquartered } \\
\text { in the country }\end{array}$ & $\begin{array}{l}\text { Yearbook of } \\
\text { International } \\
\text { Organizations } \\
\end{array}$ & + \\
\hline \multirow{6}{*}{$\begin{array}{l}\text { Bilateral } \\
\text { (Special } \\
\text { relations) }\end{array}$} & $\begin{array}{l}\text { Number of } \\
\text { Agreements }\end{array}$ & $\begin{array}{l}\text { Count of the number of } \\
\text { agreements signed with Brazil }(\log )\end{array}$ & MRE & + \\
\hline & $\begin{array}{l}\text { Expatriate } \\
\text { Community }\end{array}$ & $\begin{array}{l}\text { Estimated number of Brazilian } \\
\text { residents }\end{array}$ & MRE & + \\
\hline & G7 & G7 membership & & + \\
\hline & BRICS & BRICS membership & & + \\
\hline & Mercosul & Mercosul membership & & + \\
\hline & CPLP & CPLP membership & & + \\
\hline \multirow{4}{*}{ Bureaucratic } & Post Tradition & $\begin{array}{l}\text { 12-point scale on embassy } \\
\text { antiquity }\end{array}$ & Miscellaneous & + \\
\hline & Post Ranking & Post hierarchical ranking & MRE (via RPDN) & + \\
\hline & Linguistic Skill & $\begin{array}{l}\text { Dummy for official language(s) of } \\
\text { host country (Portuguese, English, } \\
\text { Spanish of French) }\end{array}$ & MRE/CEPII & + \\
\hline & Inertia & $\begin{array}{c}\text { Number of employees in the } \\
\text { previous year }\end{array}$ & $\begin{array}{l}\text { Lagged dependent } \\
\text { variable }\end{array}$ & + \\
\hline
\end{tabular}

Source: elaborated by the authors.

\section{Cross-sectional and panel data specifications}

Our data were configured in two different specifications: cross-section and panel data. To afford initial insight, the original dataset, which has country-year data spanning from 2008 to 2015, was averaged to produce 7-year means for all numeric variables. The complete data panel for this study comprises observations of 133 partner countries over 8 years. Panel data is expected to yield richer information than a static cross-section analysis, since dynamic effects also can be modeled. These two specifications, cross-sectional and panel data, were employed at different stages during our analysis.

\section{Results and discussions}

In order to present our results, we first describe the data on Brazilian diplomatic presence. This overview will be useful in presenting a broad picture of the distribution of Brazil's foreign policy assets. After this overview, we proceed to our regression analysis and hypotheses test. 


\section{Overview of Brazil's diplomatic presence}

Several important indicators are available at the MRE personnel lists, summarized by the RPDN dataset. We focus on three to present an overview of Brazil's diplomatic presence: number of posts, personnel size, and post ranking. Brazil's diplomatic presence in the world has undergone a significant increase. In 2008, Brasilia had a total of 186 representations in 115 countries. As of 2015, that number increased to 226 posts across 142 countries. In 2008, 1771 employees were stationed overseas, 2086 in 2015. The all-time maximum of the series was 2013, when Itamaraty registered 2115 employees abroad.

According to the Lowy Institute Global Diplomacy Index ${ }^{20}$ which counts the number of Embassies/High Commissions, Consulates/Consulates General, and Permanent Missions, Brazil ranks $9^{\text {th }}$ in the overall ranking of global diplomacy, coming behind the United States, China, France, Russia, Japan, Turkey, the United Kingdom, and Germany. Comparatively, it can be said that Brazil's diplomatic presence is amid the most important worldwide.

Concerning post raking, as previously highlighted, since 2008 stations are classified by the Ministry from A to D. Figure 2 summarizes information on post ranking, number of stations, and personnel size. The choropleth shows each city in which Brazil has a station with a circle, as of 2015. Circle color indicates post ranking, while size represents number of employees.

\section{Figure 2. Number, rank and size of Brazilian diplomatic posts in 2015}

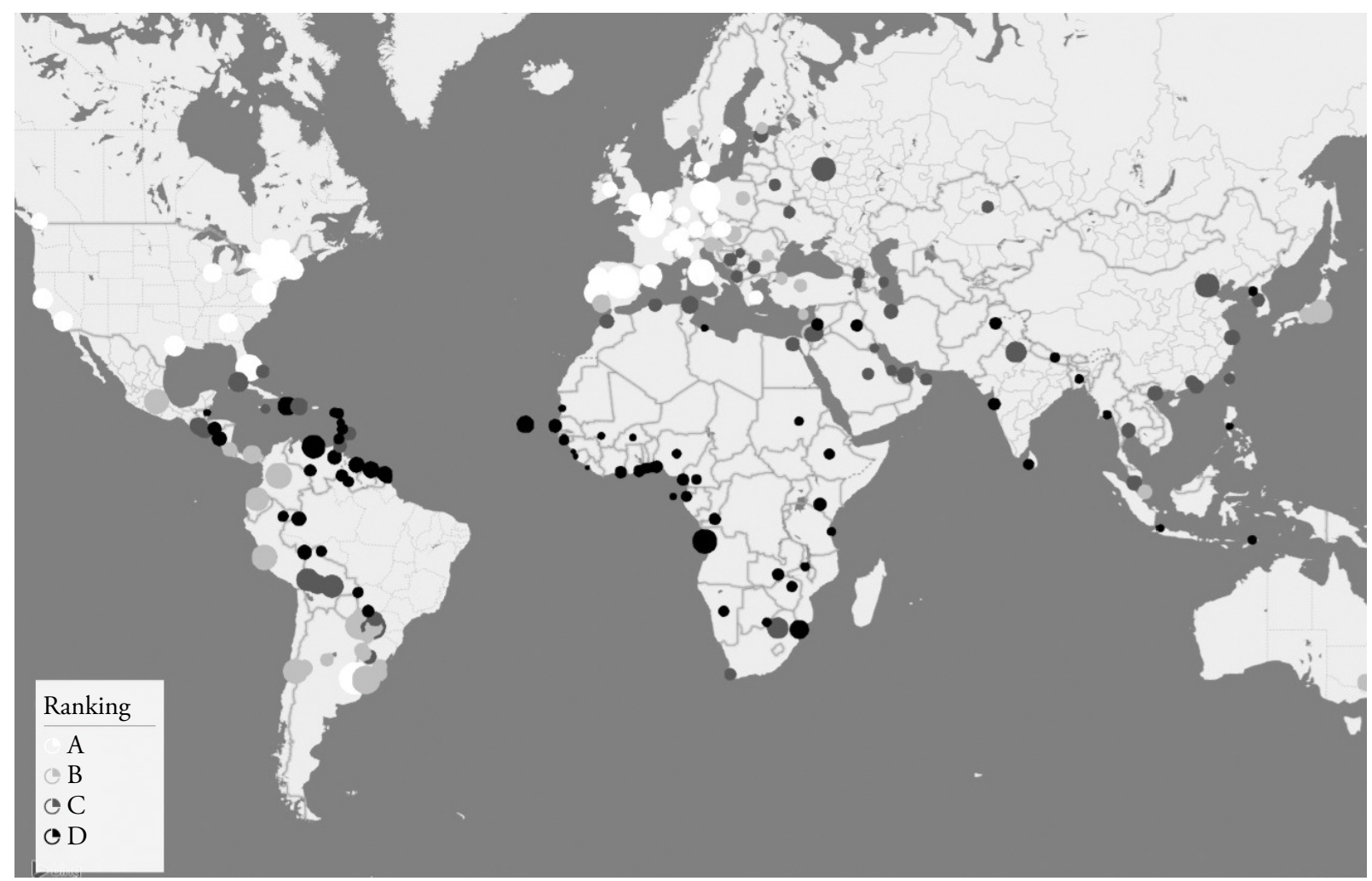

Source: elaborated by the authors, based on MRE's personnel lists. For an animated version with yearly values, see <https://1drv. $\mathrm{ms} / \mathrm{v} / \mathrm{s}$ !Au9STQ1wQqQu2HKGnayU20Cb4niV>

${ }^{20}$ Index data refers to 2017. See: https://globaldiplomacyindex.lowyinstitute.org/country_rank.html (Accessed on 25/09/2019) 
The figure reveals that the Americas concentrate the bulk of Brazil's posts and personnel (approximately 38\% of posts and 48\% of personnel). Along with the Americas, Western Europe stands out as more populated by Brazilian diplomats than other regions. With regards to post rank, North America and Western Europe alone concentrate nearly 90\% of all A posts. B stations are mainly assigned to Latin American and Caribbean countries, but they can also be found in Asia-Pacific and Eastern Europe. C and D posts are predominant in Africa, Asia and the Caribbean. By dividing the quantity of stationed employees by the number of posts, we arrive at a ratio of people per station. Table 2 shows these amounts per geographical region.

Table 2. Average number of stationed employees per post, by geographic region (2008-2015)

\begin{tabular}{lccccc}
\hline & \multicolumn{2}{c}{ Posts } & \multicolumn{2}{c}{ Personnel } & Personn./Posts ratio \\
\cline { 2 - 5 } & Mean & $\mathbf{\%}$ & Mean & $\mathbf{\%}$ & 5.3 \\
Africa & 35.6 & 17.5 & 189.4 & 10.4 & 11.1 \\
Americas & 78.4 & 38.4 & 872.6 & 48 & 6.5 \\
Asia & 26.3 & 12.9 & 170.6 & 9.4 & 10.2 \\
Europe & 44.8 & 21.9 & 457.1 & 25.1 & 8.1 \\
Oceania & 3 & 1.5 & 24.4 & 1.3 & 5.6 \\
Middle East & 14.5 & 7.1 & 81.6 & 4.5 & 14.9 \\
International Orgs. & 1.5 & 0.7 & 22.4 & 1.2 & $\mathbf{8 . 8}$ \\
Overall mean & $\mathbf{2 9 . 2}$ & $\mathbf{1 4 . 3}$ & $\mathbf{2 5 9 . 7}$ & $\mathbf{1 4 . 3}$ & \\
\hline
\end{tabular}

Source: elaborated by the authors, based on MRE's personnel lists.

As indicated, Brazil's global average is 8 to 9 people per station. The Americas and Europe are above this amount - as well as multilateral organizations, - while the remaining regions are below. Africa is the region with the least people per station, followed by the Middle East. In order to assess which factors explain these regions' rankings and staff size, we must now rely on statistical inference.

\section{Determinants of post ranking}

To what extent do the three criteria declared by the MRE (strategic significance, living conditions, and the administration's convenience) explain post ranking and which are the most relevant? From these criteria, two can be operationalized through empirical variables (strategic significance and living conditions), while the administration's discretion is beyond such direct assessments. Specifically, strategic importance was measured via country GDP and number of bilateral agreements with Brazil, while quality of life was gauged through Human Development 
Index (HDI) scores ${ }^{21}$ (all in log values). Our dependent variable, post ranking (A-D), is best conceptualized as ordinal. Hence, we utilized Ordinal Logistic Regression. For the sake of parsimony, we simplified our dataset to a cross-section, averaging the 2008-2015 values. Table 3 presents our results.

To ensure comparability, all regressors were standardized. As their natural values were logged, the numerical interpretation of the coefficients is not straightforward. Yet, it is visible that all variables were significant, being HDI the most consequential one in determining post ranking. This salience is also visible in Figure 3. The top three histograms indicate the actual frequency of posts per rank, cross-plotted over the GDP, number of agreements and HDI value ranges. The three plots below show the probability curves based on the coefficients for the same variables calculated by our model

Table 3. Results for ordinal logistic regression on post ranking

\begin{tabular}{lcc}
\hline & Stand. Coef. & Odds ratio \\
\hline GDP $(\log )$ & $0.58^{* *}$ & 1.79 \\
& $(0.28)$ & 2.30 \\
N. Agreements $(\log )$ & $0.83^{* * *}$ & 36.48 \\
HDI $(\log )$ & $(0.25)$ & \\
& $3.60^{* * *}$ & \\
Intercept & $(0.56)$ & \\
D|C & & \\
& $-0.76^{* *}$ & \\
C|B & $(0.32)$ & \\
B|A & $3.56^{* * *}$ & \\
& $(0.52)$ & \\
Observations & $6.45^{* * *}$ & \\
AIC & $(0.78)$ & \\
logLik & 134 & \\
\hline
\end{tabular}

Note: ${ }^{*} \mathrm{p}<0.1 ;{ }^{* *} \mathrm{p}<0.05 ;{ }^{* * *} \mathrm{p}<0.01$

Source: elaborated by the authors.

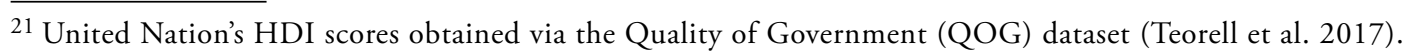


Figure 3. Empirical and theoretical distribution of post rankings for each independent variable

GDP histogram

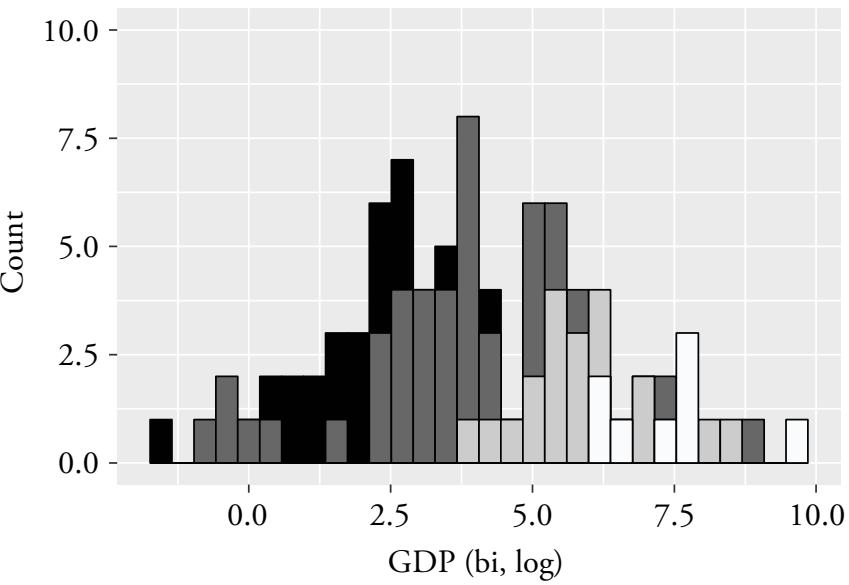

N. Agreem. histogram

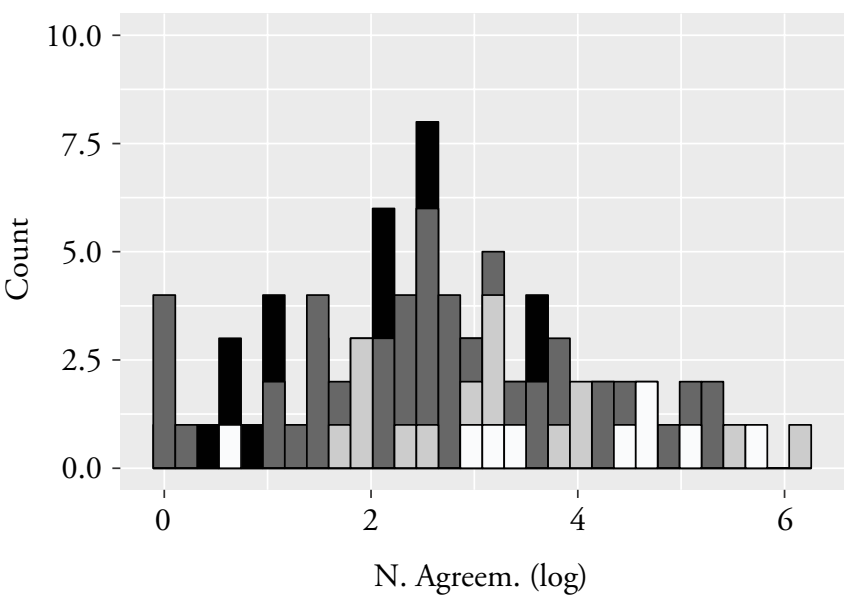

HDI histogram

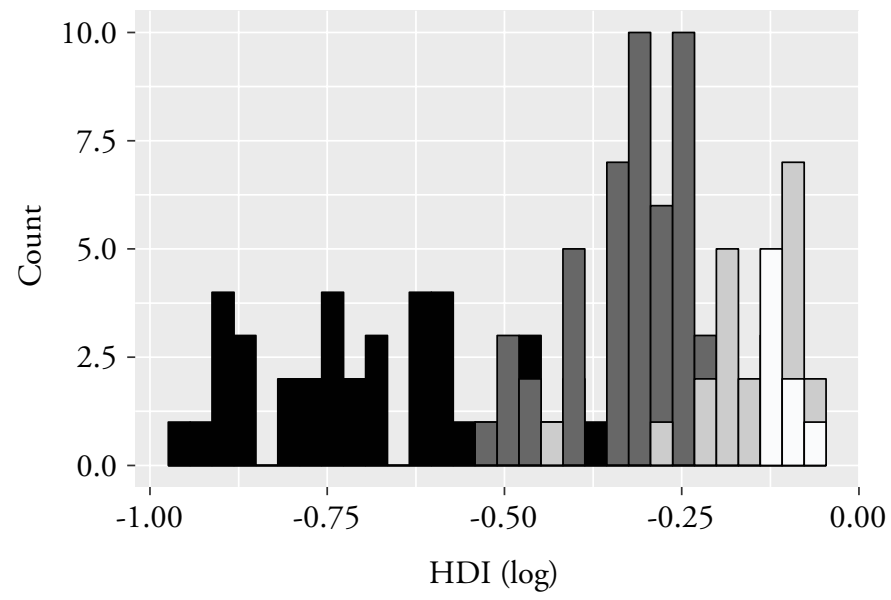

Observed Rank

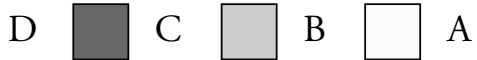

GDP $(\log )$ x Probability

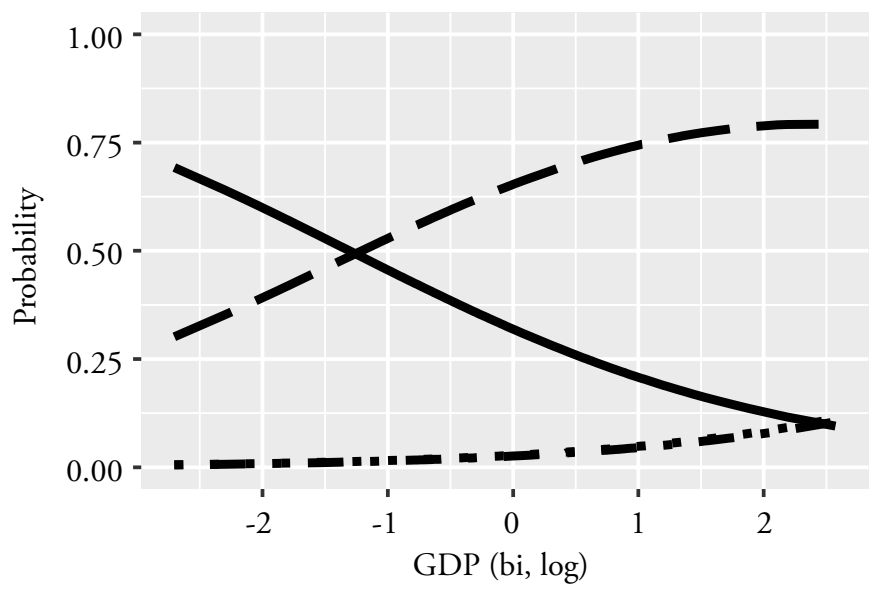

N. Agreements $(\log )$ x Probability

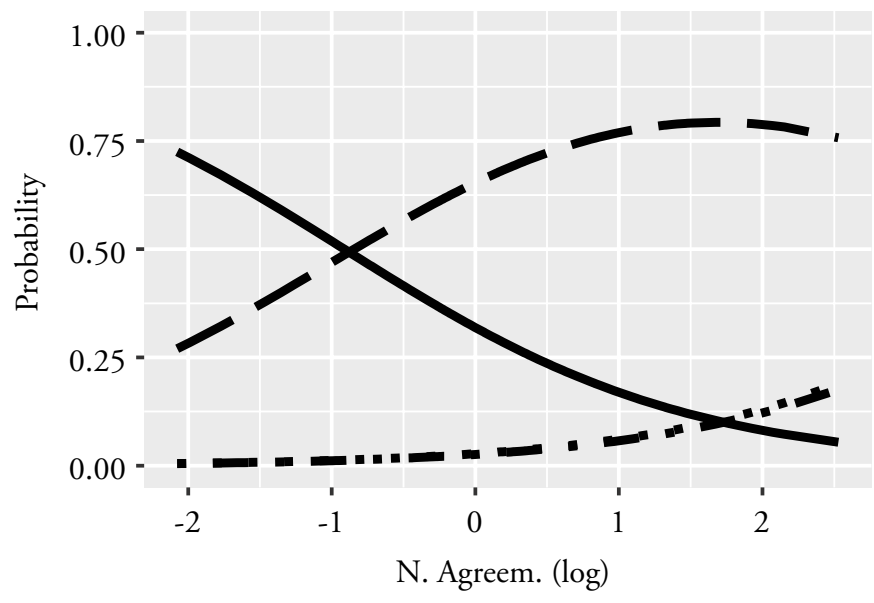

HDI $(\log )$ x Probability

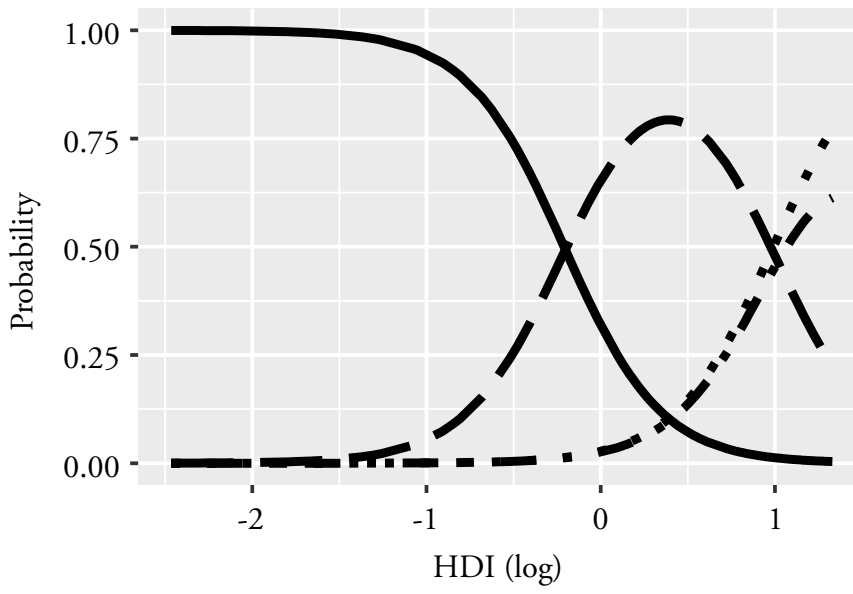

Predicted Rank

$-\mathrm{D}-\mathrm{C} \cdot \mathrm{B} \cdot \mathrm{B}$

Source: elaborated by the authors. Each curve in the bottom plots indicates the probability that a given observation will fall under a given raking, based on its GDP, number of agreements and HDI values. 
The top histograms reveal that the four hierarchical ranks are most clearly separated across the HDI dimension, while measures of GDP and number of agreements present a weaker differentiation across rankings. HDI's probability curves also reach higher values and show steeper curves, confirming this variable's strength in predicting a post ranking.

The model correctly predicted $70 \%$ of the 134 post rankings based on these three variables. For the 40 posts which were incorrectly predicted, we can conceptualize this divergence as the unobservable element of the administration's convenience. Our model misclassified D posts more often, predicting a higher ranking instead. This is perhaps indicative that the administration is more active in downgrading posts, possibly as a way to create incentives. Underestimations also occurred for higher rankings, indicating that the administration acts to lift some stations to superior grades than warranted by GDP, strategic importance and HDI. ${ }^{22}$

In conclusion, the results indicate that the criteria professed by MRE indeed affect post ranking. However, quality of life was a much stronger predictor than metrics related to strategic significance. The administration's discretion came into play more frequently in offsetting the classification of lower-order posts.

\section{Determinants of diplomatic presence}

A full investigation of the relative impact of all determinants requires multivariate regression. As expounded, we utilize both cross section and panel data. Table 4 below presents our results. Models (1) to (4) were applied to the cross-sectional version of our dataset. Model (1) applies the full OLS model with all determinants, while (2) removes two variables: GDP and Post Rank. The former was suppressed due to high collinearity ${ }^{23}$; the latter, as suggested by our analysis in Section "Determinants of post ranking," is partly caused by factors such as wealth and political importance, creating issues of endogeneity. As our main dependent variable is count data, we have also resorted to Negative Binomial regressions (Models 3 and 4). Models (5) to (6) concern our full panel. Hence, they possess time-related variables such as "inertia" (lagged dependent variable, LDV, at lags 1 and 2), " $\mathrm{t}$ " (time trend) and dummies to capture the fixed effects of each year. Pooled OLS was the preferred approach for panel data regression. ${ }^{24}$

\footnotetext{
${ }^{22}$ Cases of underestimation include some European countries of moderate importance, such as Spain and Austria, but also BRICS members, e.g.: India and South Africa. Hence, both Northern and Southern partners seem to be upgraded beyond their structural credentials by the administration's convenience.

${ }^{23}$ VIF score is greater than the recommended threshold of 10 .

${ }^{24}$ Pooled OLS is not recommended in cases of severe unit heterogeneity, as well as if serial correlation of error terms is present. We opted to use it in spite of such possible limitations because (1) alternative approaches (Fixed Effects, First Differences) prohibit us from testing time-invariant variables, which are of theoretical interest; (2) the time dynamics of the data are not expected to be severe, as this dataset has only 8 time periods but 133 countries $(\mathrm{N}>\mathrm{T})$; and (3) heterogeneity tests revealed no individual effects in our model, only year effects (Mesquita et al. 2019).
} 
Table 4. Results for multivariate regression models

\begin{tabular}{|c|c|c|c|c|c|c|}
\hline & \multicolumn{2}{|c|}{$\begin{array}{c}\begin{array}{c}\text { Number of personnel } \\
(\log )\end{array} \\
O L S\end{array}$} & \multirow{2}{*}{\multicolumn{2}{|c|}{$\begin{array}{c}\text { Number of personnel } \\
\text { (count) }\end{array}$}} & \multicolumn{2}{|c|}{$\begin{array}{c}\begin{array}{c}\text { Number of personnel } \\
(\log )\end{array} \\
\text { Pooled OLS }\end{array}$} \\
\hline & $(1)$ & & & & $(5)$ & $(6)$ \\
\hline \multicolumn{7}{|l|}{ Structural/External } \\
\hline Contiguity & $\begin{array}{l}0.91^{* * *} \\
(0.18)\end{array}$ & $\begin{array}{l}0.68^{* * *} \\
(0.16)\end{array}$ & $\begin{array}{l}0.66^{* * *} \\
(0.18)\end{array}$ & $\begin{array}{l}0.55^{* * *} \\
(0.15)\end{array}$ & $\begin{array}{c}0.19^{* * *} \\
(0.05)\end{array}$ & $\begin{array}{l}0.14^{* * *} \\
(0.05)\end{array}$ \\
\hline Distance & $\begin{array}{l}-0.00 \\
(0.00)\end{array}$ & $\begin{array}{l}-0.00 \\
(0.00)\end{array}$ & $\begin{array}{l}-0.00 \\
(0.00)\end{array}$ & $\begin{array}{l}-0.00 \\
(0.00)\end{array}$ & $\begin{array}{l}-0.00 \\
(0.00)\end{array}$ & $\begin{array}{l}-0.00 \\
(0.00)\end{array}$ \\
\hline GDP $(\log )$ & $\begin{array}{l}0.08^{* *} \\
(0.04)\end{array}$ & & $\begin{array}{c}0.05 \\
(0.05)\end{array}$ & & $\begin{array}{c}0.01 \\
(0.01)\end{array}$ & \\
\hline Trade $(\log )$ & $\begin{array}{c}0.01 \\
(0.02)\end{array}$ & $\begin{array}{c}0.02 \\
(0.02)\end{array}$ & $\begin{array}{c}0.06 \\
(0.04)\end{array}$ & $\begin{array}{l}0.06^{* *} \\
(0.03)\end{array}$ & $\begin{array}{c}0.01 \\
(0.01)\end{array}$ & $\begin{array}{c}0.02^{* * *} \\
(0.01)\end{array}$ \\
\hline N. IGOs & $\begin{array}{c}0.01 \\
(0.01)\end{array}$ & $\begin{array}{l}0.01^{*} \\
(0.01)\end{array}$ & $\begin{array}{l}0.01^{*} \\
(0.01)\end{array}$ & $\begin{array}{l}0.01^{* *} \\
(0.01)\end{array}$ & $\begin{array}{c}0.01 \\
(0.01)\end{array}$ & $\begin{array}{c}0.01 \\
(0.01)\end{array}$ \\
\hline \multicolumn{7}{|c|}{ Special Relation Status } \\
\hline N. Agreem. $(\log )$ & $\begin{array}{c}0.01 \\
(0.04)\end{array}$ & $\begin{array}{c}0.01 \\
(0.04)\end{array}$ & $\begin{array}{c}0.07 \\
(0.05)\end{array}$ & $\begin{array}{c}0.07 \\
(0.05)\end{array}$ & $\begin{array}{c}0.01 \\
(0.01)\end{array}$ & $\begin{array}{c}0.01 \\
(0.01)\end{array}$ \\
\hline N. BR Resid. (log) & $\begin{array}{l}0.09^{* * *} \\
(0.02)\end{array}$ & $\begin{array}{l}0.12^{* * *} \\
(0.02)\end{array}$ & $\begin{array}{l}0.13^{* * *} \\
(0.02)\end{array}$ & $\begin{array}{l}0.14^{* * *} \\
(0.02)\end{array}$ & $\begin{array}{c}0.02^{* * *} \\
(0.01)\end{array}$ & $\begin{array}{l}0.03^{* * *} \\
(0.01)\end{array}$ \\
\hline G7 & $\begin{array}{l}0.71^{* * *} \\
(0.16)\end{array}$ & $\begin{array}{c}0.77^{* * *} \\
(0.17)\end{array}$ & $\begin{array}{c}0.47^{* * *} \\
(0.15)\end{array}$ & $\begin{array}{l}0.51^{* * *} \\
(0.15)\end{array}$ & $\begin{array}{l}0.16^{* * *} \\
(0.05)\end{array}$ & $\begin{array}{l}0.16^{* * *} \\
(0.05)\end{array}$ \\
\hline BRICS & $\begin{array}{c}0.74^{* * *} \\
(0.17)\end{array}$ & $\begin{array}{c}0.78^{* * *} \\
(0.18)\end{array}$ & $\begin{array}{l}0.62^{* * *} \\
(0.17)\end{array}$ & $\begin{array}{c}0.64^{* * *} \\
(0.17)\end{array}$ & $\begin{array}{l}0.17^{* * *} \\
(0.04)\end{array}$ & $\begin{array}{l}0.16^{* * *} \\
(0.04)\end{array}$ \\
\hline Mercosul & $\begin{array}{l}0.77^{* * *} \\
(0.22)\end{array}$ & $\begin{array}{l}0.88^{* * *} \\
(0.23)\end{array}$ & $\begin{array}{c}0.55^{* * *} \\
(0.16)\end{array}$ & $\begin{array}{c}0.60^{* * *} \\
(0.16)\end{array}$ & $\begin{array}{l}0.11^{* *} \\
(0.05)\end{array}$ & $\begin{array}{l}0.11^{* *} \\
(0.05)\end{array}$ \\
\hline CPLP & $\begin{array}{l}0.65^{* * *} \\
(0.16)\end{array}$ & $\begin{array}{c}0.43^{* * *} \\
(0.15)\end{array}$ & $\begin{array}{c}0.51^{* * *} \\
(0.17)\end{array}$ & $\begin{array}{l}0.40^{* *} \\
(0.16)\end{array}$ & $\begin{array}{l}0.10^{* *} \\
(0.05)\end{array}$ & $\begin{array}{c}0.07 \\
(0.04)\end{array}$ \\
\hline Bureaucratic Factor & & & & & & \\
\hline Post Tradition & $\begin{array}{l}0.04^{* *} \\
(0.02)\end{array}$ & $\begin{array}{l}0.06^{* * *} \\
(0.02)\end{array}$ & $\begin{array}{c}0.03 \\
(0.02)\end{array}$ & $\begin{array}{l}0.05^{* * *} \\
(0.02)\end{array}$ & $\begin{array}{c}0.01 \\
(0.01)\end{array}$ & $\begin{array}{l}0.01^{*} \\
(0.01)\end{array}$ \\
\hline Post Rank & $\begin{array}{l}0.14^{* *} \\
(0.06)\end{array}$ & & $\begin{array}{c}0.06 \\
(0.07)\end{array}$ & & $\begin{array}{c}0.02 \\
(0.02)\end{array}$ & \\
\hline Language & $\begin{array}{c}0.13^{*} \\
(0.08)\end{array}$ & $\begin{array}{c}0.02 \\
(0.07)\end{array}$ & $\begin{array}{l}0.20^{* *} \\
(0.09)\end{array}$ & $\begin{array}{c}0.13 \\
(0.09)\end{array}$ & $\begin{array}{l}0.05^{*} \\
(0.03)\end{array}$ & $\begin{array}{c}0.03 \\
(0.03)\end{array}$ \\
\hline LDV1 & & & & & $\begin{array}{c}0.60^{* * *} \\
(0.04)\end{array}$ & $\begin{array}{c}0.60^{* * *} \\
(0.04)\end{array}$ \\
\hline LDV2 & & & & & $\begin{array}{l}0.17^{* * *} \\
(0.04)\end{array}$ & $\begin{array}{l}0.18^{* * *} \\
(0.04)\end{array}$ \\
\hline $\mathrm{t}$ & & & & & $\begin{array}{l}-0.01 \\
(0.01)\end{array}$ & $\begin{array}{l}-0.01 \\
(0.01)\end{array}$ \\
\hline Constant & $\begin{array}{c}0.56 \\
(0.42)\end{array}$ & $\begin{array}{c}0.36 \\
(0.30)\end{array}$ & $\begin{array}{l}-0.72 \\
(0.64)\end{array}$ & $\begin{array}{l}-0.66 \\
(0.42)\end{array}$ & $\begin{array}{l}-0.06 \\
(0.15)\end{array}$ & $\begin{array}{l}-0.14 \\
(0.11)\end{array}$ \\
\hline Observations & 135 & 138 & 135 & 138 & 925 & 925 \\
\hline $\mathrm{R}^{2}$ & 0.90 & 0.88 & & & 0.92 & 0.92 \\
\hline Adjusted $\mathrm{R}^{2}$ & 0.88 & 0.87 & & & 0.92 & 0.92 \\
\hline F Statistic & $\begin{array}{c}73.97^{* * *} \\
(\mathrm{df}=14 ; 120)\end{array}$ & $\begin{array}{c}77.58^{* * *} \\
(\mathrm{df}=12 ; 125)\end{array}$ & & & $\begin{array}{c}451.44^{* * *} \\
(\mathrm{df}=23 ; 901)\end{array}$ & $\begin{array}{c}493.61^{* * *} \\
(\mathrm{df}=21 ; 903)\end{array}$ \\
\hline
\end{tabular}

Note: ${ }^{*} \mathrm{p}<0.1 ;{ }^{* *} \mathrm{p}<0.05 ;{ }^{* * *} \mathrm{p}<0.01$

Source: elaborated by the author. Values were not mean-centered. Dummies for individual year effects on Models (5) and (6) omitted from the table to improve readability. The years 2010 and 2011 presented a statistically significant positive effect on number of personnel, in contrast to baseline year 2008. Heteroskedasticity and autocorrelation robust SE were used for panel data ("Arellano" approach at the R plm package). 
Results indicate that structural factors were not prevalent. While contiguity was consistently relevant in all models, GDP and trade displayed the expected positive effects, but their significance tended to vary. Headquartering IGOs was significant particularly for the negative binomial models, though with small effects. The determinants relating to special bilateral relations, in turn, were thoroughly relevant. Membership in the G7, BRICS, Mercosul and CPLP were relevant in all six models. Perhaps due to the combined effect of these dummies, which capture the bulk of Northern and Southern nations that attract Brazilian foreign policy, the variable counting the number of bilateral agreements was emptied of its effect. As all four political groupings are dummies, their coefficients can be directly compared. Hence, belonging to the CPLP produces a more modest effect in comparison to membership in the other three groups. The Mercosul, G7 and BRICS groupings elicited the greatest effect over personnel size. However, since their magnitude in relation to one another varied across models, it is difficult to ascertain which bloc is the most influential. It can be noted, nonetheless, that their differences are within error ranges, and that some of the weight of G7 countries is shared with other variables, such as number of hosted IGOs.

Bureaucratic determinants presented the expected effects and were fairly consistent. Post tradition was statistically relevant in most models, albeit with timid effects. The effect of linguistic skills was stronger, but only relevant in the presence of post ranking. Bureaucratic inertia could only be tested in models (5) and (6) through the inclusion of LDVs. Due to serial correlation, two lags were needed. Their coefficients indicate that the previous number of employees is a strong determinant of future size. Overall, the magnitude of the coefficients detected by the panel data analyses was more modest than the other models'. This is expected, due to the inclusion of LDVs and year-effect dummies.

As not all determinants were in the same scale, we standardized models (1), (3) and (5), containing all variables of interest, so as to obtain an approximate reading of which factors were more important in determining personnel placement. The results are presented in Figure 4, which shows the beta-coefficients for all determinants, along with confidence intervals.

Though the magnitude of the effects of the three models differed, they tended to concur in terms of relative importance and direction. In order of relevance, the number of Brazilian residents, geographical contiguity and bloc membership (particularly the G7) consistently provided the foremost determinants. However, the Pooled OLS results also reveal overwhelming influence of diplomatic inertia (LDVs). In addition, all models predicted a similar intercept of approximately 2 , indicating that, when all determinants are held at their mean values, the number of stationed personnel should be of approximately $\exp ^{2}=7$ people. 
Figure 4. Standardized coefficients for models (1), (3) and (5).

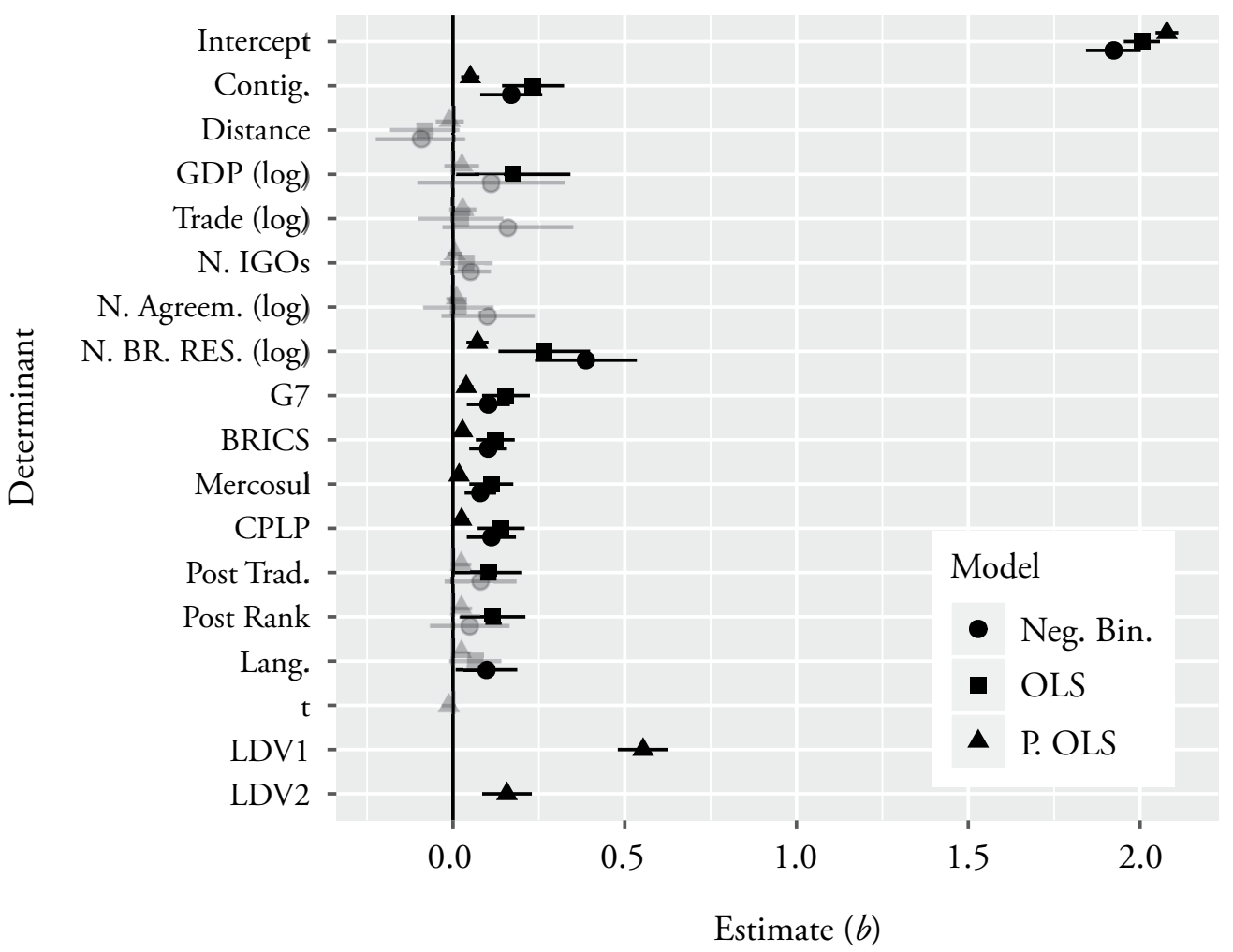

Source: elaborated by the authors. Statistically significant values at $p<0.05$ are colored black. ${ }^{25}$

In summary, the findings are suggestive that a few elements are steadily influential in determining staff size. The predominance of the number of Brazilian residents indicates that MRE's decision to allocate personnel is strongly motivated by practical, service-related matters, that is, to provide consular support to the expatriate community. Yet, it is difficult to disentangle its effect from that of country wealth, as Brazilians tend to migrate to more prosperous nations. 26

Group membership was also thoroughly relevant, further confirming the importance of elements pertaining to bilateral relation status in explaining diplomatic presence. The narrow gap between the G7 and the BRICS is a sign that Itamaraty has been duly responsive to changes in international polarity, though no complete reversal can be asserted. Though BRICS countries exerted a strong pull, the effects of bureaucratic elements testify to the prolonged importance of traditional centers. The influence of post tradition (centennial stations were preferred to newer ones) and above all inertia indicate that Brazilian diplomats still attach great value to prestigious locations.

\footnotetext{
${ }^{25}$ Note that only the independent variables were standardized to ensure comparability (dependent variables in negative binomial models cannot assume negative values). Hence, the beta-coefficients (b) must be interpreted as: an increase in +1 SD in the independent variable produces a $b$-fold increase in the dependent variable. As the dependent variable (number of personnel) is in log, the actual increase in number of people is equal to $\exp ^{\mathrm{b}}$. Standardized coefficients are not widely used for Pooled OLS regression, so that its outcomes must be interpreted parsimoniously.

${ }^{26}$ For the sake of parsimony, an attempt to disentangle both effects was reserved for the article's Annex only. (Mesquita et al. 2019).
} 
Lastly, the region also stood out as consistently important, as displayed by the high impact of geographical contiguity and Mercosul membership. In fact, the added effects of these two variables suggests that Brazilian diplomatic presence in certain key South American neighbors can outweigh the staff size in other global destinations.

\section{Conclusion}

This research sought to assess the impact of several determinants on Brazil's diplomatic presence. In particular, we set out to gauge the distribution of Brazilian posts and personnel; test the relative impact of MRE's criteria in determining post ranking; and also the weight of structural, bilateral and institutional aspects in shaping the allocation of diplomatic staff.

Our overview of Brazilian diplomatic presence revealed a high concentration in the Americas and in Europe. Other regions of growing economic importance, such as Asia, or which are at least rhetorically emphasized, like Africa, remain under populated. We also concluded that the MRE abides to its official criteria in determining post ranking, with quality of life being the most relevant factor. In addition, the Ministry seems to be more discretionary in downgrading stations, perhaps to increase incentives. Yet, in light of the previously mentioned personnel scarcity in Africa and Asia, this inducement seems to be of little success.

As for the determinants of diplomatic presence, factors pertaining to bilateral relations were consistently relevant. The weight of the expatriate community indicates that personnel placement is a labor-driven decision, that is, a response to local demands for consular services. In addition, countries enjoying some form of special relation vis-à-vis Brazil were much more likely to host larger missions. BRICS countries also displayed a sizeable attraction in comparison to other groups, though it is hard to discern a clear superiority. Nonetheless, it is clear that Brazil's engagement with emerging poles goes beyond rhetoric: it has been substantiated through the costly gesture of mission size expansion.

The importance of regional neighbors, either due to Mercosul membership or contiguity, was also noticeable. The combined relevance of these elements propelled a few South American States well above some global partners, - G7 and BRICS alike. Hence, our analysis indicates that Brazil still places sizeable worth on its regional peers, even in face of its growing global profile.

The powerful effect of bureaucratic factors, chiefly inertia, reflects a preference for continuity. Current mission size was strongly affected by previous levels, which indicates that year after year diplomats tend flock to (or avoid) the same destinations. As an organization facing a changing environment, Itamaraty employees seem to remain sternly attached to traditional preferences. Nonetheless, as our conclusions regarding time-related factors were afforded by a rather simple Pooled OLS model, these dynamic aspects can be further explored by later studies employing more sophisticated models to account for spatial and temporal heterogeneities and interdependencies. 
Other strands of future research can productively complement the current findings. Though we ventured to identify causal relations, without additional in-depth analysis our evidence remains correlational at best. This particularly concerns qualitative studies delving deeper into the matter of how mission sizes are determined, or into MRE employees' perspective concerning career-building strategies and on how they decide on which destination to serve.

\section{Acknowledgements}

The authors relied on funding by CAPES ( $\mathrm{n}^{\circ}$ 88881.132436/2016-01) and CNPq $\left(n^{\circ} 303247 / 2015-0\right.$ and 133953/2018-1). An early draft of this article was presented at the $14^{\text {th }}$ Congress of the Association Française de Science Politique (AFSP) in Montpellier, France, 2017, also through the support of a joint grant between AFSP and the Associação Brasileira de Ciência Politica (ABCP).

\section{References}

Almeida, M. H., J. Onuki, and L. P. Carneiro. Brasil, as Américas e o mundo: opinião pública e politica externa 2010 - 2011. São Paulo, SP: Universidade de São Paulo, 2012.

Art, R. J. "Bureaucratic politics and american foreign policy: a critique." Policy Sciences 4, no. 4 (1973): 467-490. doi: https://doi.org/10.1007/BF01728472

Bancillon, D. "Após décadas de glamour, diplomacia brasileira acumula dívidas." GQ, January 23, 2016. http://gq.globo.com/Prazeres/Poder/noticia/2016/01/ aposdecadasdeglamourdiplomaciabrasileiraacumuladividas.html

Bennett, C. J., and M. Howlett. "The lessons of learning: reconciling theories of policy learning and policy change." Policy sciences 25, no. 3 (1992): 275-294. doi: https://doi.org/10.1007/BF00138786

Brams, S. J. "Transaction flows in the international system." American Political Science Review 60, no. 4 (1966): 880-898. doi: https://doi.org/10.2307/1953763

Brasil. Decreto no. 93.325, de 1 de outubro de 1986. Aprova o regulamento de pessoal do serviço exterior. Diário Oficial da União, October 3, 1986. http://www.planalto.gov.br/ ccivil_03/decreto/Antigos/D93325.htm

Brasil. Decreto no. 5.979, de 6 de dezembro de 2006. Aprova a estrutura regimental e o quadro demonstrativo dos cargos em comissão e das funçôes de confiança do Ministério das Relações Exteriores, remaneja cargos em comissão e funções gratificadas e substitui cargos em comissão do Grupo Direção e Assessoramento Superior-DAS por Funções Comissionadas Técnicas do Poder Executivo Federal - FCPE. Diário Oficial da União, July 7, 2006a. http://www. planalto.gov.br/ccivil_03/_Ato2015-2018/2016/Decreto/D8817.htm\#art10 
Brasil. Decreto no. 9.683, de 9 de janeiro de 2019. Aprova a estrutura regimental e o quadro demonstrativo dos cargos em comissão e das funçóes de confiança do Ministério das Relações Exteriores, remaneja cargos em comissão e funçóes de confiança e transforma Funçóes Comissionadas do Poder Executivo - FCPE. Diário Oficial da União, January 10, 2019. http://www.planalto.gov.br/ccivil_03/_Ato20192022/2019/Decreto/D9683.htm

Brasil. Lei no. 11.440, de 29 de dezembro de 2006. Institui o Regime Jurídico dos Servidores do Serviço Exterior Brasileiro, altera a Lei no 8.829, de 22 de dezembro de 1993, que cria, no Serviço Exterior Brasileiro, as Carreiras de Oficial de Chancelaria e de Assistente de Chancelaria, altera a Lei no 8.829, de 22 de dezembro de 1993; revoga as Leis $n^{\circ}$ s 7.501, de 27 de junho de 1986, 9.888, de 8 de dezembro de 1999, e 10.872, de 25 de maio de 2004, e dispositivos das Leis $\mathrm{n}^{\mathrm{o}} \mathrm{s}$ 8.028, de 12 de abril de 1990, 8.745, de 9 de dezembro de 1993, e 8.829, de 22 de dezembro de 1993; e dá outras providências. Diário Oficial da União, December 29, 2006b. http://www.planalto.gov.br/ccivil_03/_ ato2004-2006/2006/lei/L11440.htm

Braun, J. "Itamaraty fecha cinco embaixadas brasileiras no Caribe." Veja, June 4, 2019. https://veja.abril.com.br/mundo/itamaraty-fecha-cinco-embaixadas-brasileiras-no-caribe/

Cason, J., and T. Power. "Presidentialization, pluralization, and the rollback of Itamaraty: explaining change in brazilian foreign policy making in the Cardoso-Lula era."

International Political Science Review 30, no. 2 (2009): 117-140.

doi: https://doi.org/10.1177/0192512109102432

Cheibub, Z. "Diplomacia e construção institucional: o Itamaraty em perspectiva histórica." Dados: Revista de Ciências Sociais 28, no. 1 (1985): 113-131.

Cooper, A. F. "Squeezed or revitalised? Middle powers, the G20 and the evolution of global governance." Third World Quarterly 34, no. 6 (2013): 963-984. doi: https://doi.org/10.1 080/01436597.2013.802508

Crozier, M. Le phénomène bureaucratique. Paris: Seuil, 1971.

Douglas, M. How institutions think. New York, NY: Syracuse University, 1986.

Duque, M. G. "Recognizing international status: a relational approach.” International Studies Quarterly 62, no. 3 (2018): 577-592. doi: https://doi.org/10.1093/isq/sqy001

Farias, R., and G. Carmo. "Do circuito elizabeth arden ao circuito global? A política de postos e remoçóes do Itamaraty." Mundorama, June 16, 2015 . https://www.mundorama. net/?p=15959

Figueira, A. R. "Rupturas e continuidades no padrão organizacional e decisório do ministério das relaçóes exteriores." Revista Brasileira de Politica Internacional, 53 no. 2 (2010): 5-22. doi: https://doi.org/10.1590/S0034-73292010000200001

Fonseca Jr, G. A legitimidade e outras questóes internacionais. São Paulo, SP: Paz e Terra, 1998. 
Girglioli, P. P. "Burocracia.” In Dicionario de politica, edited by N. Bobbio, N. Matteucci, and G. Pasquino. Brasília, DF: Universidade de Brasília, 1997.

Hampson, F. O., C. A. Crocker, and P. Aall. "Negotiation." In The Oxford handbook of modern diplomacy, edited by A. F. Cooper, J. Heine, and R. Thakur, 319-336. Oxford: Oxford University, 2013.

Hocking, B., and D. Lee. “The diplomacy of proximity and specialness: enhancing Canada's representation in the United States." The Hague Journal of Diplomacy 1, no. 1 (2006): 29-52. doi: https://doi.org/10.1163/187119006X101889

Jacobs, L. M., and R. Rossem. "The BRIC phantom: a comparative analysis of the BRICs as a category of rising powers." Journal of Policy Modeling 36, suppl. 1 (2014): S47-S66. doi: https://doi.org/10.1016/j.jpolmod.2013.10.008

Karns, M. P., and K. A. Mingst. "International organizations and diplomacy." In The Oxford handbook of modern diplomacy, edited by A. F. Cooper, J. Heine, and R. Thakur, 142-159. Oxford: Oxford University, 2013.

Kinne, B. J. "Dependent diplomacy: signaling, strategy, and prestige in the diplomatic network." International Studies Quarterly 58, no. 2 (2014): 247-259. doi: https://doi. org/10.1111/isqu.12047

Lazarou, E., and B. L. Theodoro. "Regionalism as an instrument: assessing Brazil's relations with its neighbourhood.” Global Society 29, no. 3 (2015):1-19. doi: https://doi.org/10.1 080/13600826.2015.1039500

Lessa, A. C., and H. A. Oliveira. Parcerias estratégias do Brasil: os significados e as experiências tradicionais. vol. 1. Belo Horizonte, MG: Fino Traço, 2013.

Lima, J. A. "A cooperação internacional sul-sul e a difusão de políticas: uma análise exploratória das políticas coordenadas pela Agência Brasileira de Cooperação.” Master Diss. Universidade Federal de Pernambuco, 2014.

Lopes, D. B. “Da razão de estado ao republicanismo mitigado: uma narrativa faoriana sobre a produção da política externa brasileira.” Dados: Revista de Ciências Sociais 57, no. 2 (2014): 481-516. doi: https://doi.org/10.1590/0011-5258201415

McLean, I., A. McMillan. "Bureaucracy." In Oxford concise dictionary of politics, edited by I. McLean, and A. McMillan. Oxford: Oxford University, 2009.

Malamud, A., and J. C. C. Rodrigues. "Straddling the region andthe world: Brazil's dual foreignpolicy comes of age." In The role, position and agency of cusp states in international relations, edited by Marc Herzogand Philip Robins, 111-128. New York, NY: Routledge, 2014.

Mello, P. C., and J. Nublat. "Serra pede estudo de custo de embaixadas na África e no Caribe." Folha de São Paulo, May 17, 2016. Accessed May 19, 2019. https://www1.folha. uol.com.br/mundo/2016/05/1771982-serra-pede-estudo-de-custo-de-embaixadas-naafrica-e-no-caribe.shtml. 
Mesquita, R. “A identidade internacional do Brasil: uma síntese da literatura.” Carta Internacional 11, no. 3 (2016): 5-31. doi: https://doi.org/10.21530/ci.v11n3.2016.496. Mesquita, R. "Introducing the rising powers diplomatic network (RPDN): a dataset for rising powers' presidential diplomacy and diplomatic presence abroad." Rising Powers Quarterly 3, no. 4 (2019): 7-31. doi: https://doi.org/10.7910/DVN/5FISNQ

Mesquita, R., and M. A. Medeiros. "Legitimising emerging power diplomacy: an analysis of government and media discourses on brazilian foreign policy under Lula.” Contexto internacional 38, no. 1 (2016): 385-432. https://doi.org/10.1590/S01028529.2016380100011

Mesquita, R., M. A. Medeiros, and L. V. Amelotti. "Replication data for: diplomats, Quo Vadis? The determinants of brazilian diplomatic presence.” Harvard Dataverse 1, (2019). https://doi.org/10.7910/DVN/53KIX8

Ministério das Relaçóes Exteriores. Portaria no. 212, de 30 de abril de 2008. Diário Oficial da União, May 1, 2008.

Neumayer, E. "Distance, power and ideology: diplomatic representation in a world of nation-states." Area 40, no. 2 (2008): 228-236.

Rodrigues, P., F. Urdinez, and A. Oliveira. "Measuring international engagement: systemic and domestic factors in brazilian foreign policy from 1998 to 2014 ." Foreign Policy Analysis 15, no. 3 (2019): 370-391. doi: https://doi.org/10.1093/fpa/orz010

Saraiva, M. G. "A diplomacia brasileira e as visões sobre a inserção externa do Brasil: institucionalistas pragmáticos x autonomistas." Mural internacional 1, no. 1 (2010): 45-52. doi: https://doi.org/10.12957/rmi.2010.5285

Silva, L. I. L. Discurso do Presidente da República, Luiz Inácio Lula da Silva, na cerimônia de inauguração da embaixada do Brasil na República Democrática de São Tome e Príncipe. Brasília, DF: Presidência da República, 2003. Accessed on May 18, 2019. http://www.biblioteca.presidencia.gov.br/presidencia/ex-presidentes/luiz-inacio-lula-dasilva/discursos/1o-mandato/2003/02-11-2003-discurso-do-pr-luiz-inacio-lula-da-silvana-cerimonia-de-inauguracao-da-embaixada-do-brasil.pdf

Singer, J. D., and M. Small. "The composition and status ordering of the international system: 1815-1940.” World Politics 18, no. 2 (1966): 236-282.

Small, M., and J. D. Singer. "The diplomatic importance of states, 1816-1970: an extension and refinement of the indicator." World Politics 25, no. 4 (1973): 577-599. doi: https:// doi.org/10.2307/2009953

Smith, S. “The special relationship.” Political Studies 38, no. 1 (1990): 126-136. doi: https:// doi.org/10.1111/j.1467-9248.1990.tb00574.x

Spektor, M. "Ideias de ativismo regional: a transformação das leituras brasileiras da região." Revista Brasileira de Politica Internacional 53, no. 1 (2010): 25-44. doi: https://doi. org/10.1590/S0034-73292010000100002 
Steiner, A. Q., M. A. Medeiros, and R. M. S. Lima."From Tegucigalpa to Teheran: Brazil's diplomacy as an emerging western country." Revista Brasileira de Politica Internacional 57, no. 1 (2014):40-58. doi: https://doi.org/10.1590/0034-7329201400103

Stuenkel, O. "Brazilian foreign policy: into the dark." Post-Western World, December 12, 2014. Accessed May 18, 2019. http://www.postwesternworld.com/2014/12/12/brazilianforeign-policy-into/

Teorell, J., S. Dahlberg, S. Holmberg, B. Rothstein, A. Khomenko, and R. Svensson. The quality of government standard dataset, version Jan 17. Gothenburg: University of Gothenburg, 2017. http://www.qog.pol.gu.se

Teixeira, M. C., and A. Q. Steiner. "As mulheres na carreira diplomática brasileira: considerações sobre admissão, hierarquia e ascensão profissional." Monçôes: Revista de Relaçôes Internacionais da UFGD 6, no. 11 (2017): 250-280. doi: https://doi. org/10.30612/rmufgd.v6i11.6918

Vigevani, T., and G. Cepaluni. A politica externa brasileira: a busca da autonomia, de Sarney a Lula. São Paulo, SP: Universidade Estadual Paulista, 2011.

Wallace, M. D. “Power, status, and international war." Journal of Peace Research 8, no. 1 (1971): 23-35. doi: https://doi.org/10.1177/002234337100800103

Webster, C. "Commonwealth diplomatic missions." The Roundtable 361, (2001): 529-539.

Webster, C., and E. Hadjimanoli. "The placement of cypriot embassies and embassy staff." The Cyprus Review 26, n. 2 (2014): 105-126.

Webster, C., and S. Ivanov. "Placement of romanian and bulgarian embassies: EU aspirations and comunist legacy." South-Eastern Europe Journal of Economics 5, no. 1, (2007): 77-94.

Wouters, J., S. Duquet, and K. Meuwissen. "The Vienna conventions on diplomatic and consular relations." In The Oxford handbook of modern diplomacy, edited by A. F. Cooper, J. Heine and R. Thakur, 510-543. Oxford: Oxford University, 2013. 